\title{
Macbeth as a Tragedy of Consciousness on the Hungarian Stage after 1989
}

\author{
Attila Kiss
}

In totalitarian systems, it would be difficult to find a Shakespearean play that lends itself better to political thematization than Macbeth, and the theatrical reception history of this tragedy in East-Central Europe is certainly indicative of how it has been employed to reflect on the current antagonisms of the country. Gradual but significant changes occurred in this reception during the past twenty-five years, after the fall of the Iron Curtain. Even if it has become a critical commonplace that the various modes of social and artistic expression had to redefine themselves after the changing regime in the former socialist block, we must observe the socio-political constraints of the period in which I would like to survey the history of Macbeth productions in Hungary. Before 1989, the theatrical scene in East-Central Europe was the field where perhaps the most intensive artistic experimentations were always combined, through the "double talk" or double coding of covert intellectual messages, with political awareness and subversive ideological critique. The theatre gradually developed a capacity to operate the mechanism of semiotic overdetermination or overcoding on two levels. ${ }^{1}$ Other than the semiotization of every object on the stage, this overcoding functioned on a second level in the time of political censorship, since spectators and critics were constantly on the watch, looking out for meanings that could turn the theatrical representation into political allegory or a criticism of some aspect of the establishment. From the 1990s onwards, the theatre, like literature and cinema, gradually started to lose this political potentiality that could always guarantee some success if the performance was radical enough. This was, however, not only a loss of revolutionary opportunities, but also an emancipatory change, since the artistic expression no longer had to meet the expectations of a political horizon. The real liberation of the theatre was not only in the fact that it was no longer censored by the apparatus of party ideology, but through the break with the compulsory double talk of politicization that, for many, was the touchstone of artistic quality.

\footnotetext{
${ }^{1}$ As is known in theatre semiotics, every object that appears on the stage is automatically presumed by the spectator to carry some kind of meaning, even if there is no intention in the performance-text for such a semantic function. As Terence Hawkes observes, a pimple on the nose of the actor playing Hamlet will be readily interpreted by the audience as an emblematic representation of the fallibility of humankind, the corruption of the flesh and the general condition of the state, even if this has not been intended by the actor or the director. See his "Shakespeare and New Critical Approaches," in The Cambridge Companion to Shakespeare Studies, ed. Stanley Wells (Cambridge: Cambridge University Press, 1986), 294.
} 
This was, of course, a gradual transition, and, as it soon turned out, the political overtones or allegorizing affinities were far from becoming totally unpopular or groundless the political changes resulted in ideological structures that continued to invite or provoke satirical social criticism. The generic political overcoding of double talk was certainly over, but the great productions on the Hungarian stages after 1989 bear the traces of the previous period, and had to attempt the renewal of the representational techniques and themes of the Hungarian theatre together while continuing the heritage of the former masters.

In what follows I will survey stage productions of Shakespeare's Macbeth in Hungary in the two decades after the political changes, and go back to the early 1980s to touch upon two cinematographic attempts that had a long-lasting effect on the theatrical and visual consciousness of Hungarian directors to come. ${ }^{2}$

It is impossible to provide an interpretive evaluation of Shakespeare adaptations without a theoretical framework and specific aspects that establish a single perspective. My contention is that the two film adaptations I start with introduced this single perspective in Hungary as a vision of Shakespeare's great tragedies that retained a determining influence for the three decades that followed. This vision is based on the understanding of Shakespeare's Hamlet and Macbeth as tragedies of consciousness. This concept was theorized, among other scholars, by John Bayley who argues that these two tragedies, together with Othello:

[...]enter and possess the mind and instantly become a part of it. Indeed, immensely realistic as they are, they seem to take place in an area of thinking, feeling and suffering that has taken over from life, in the same way that the area of the play has taken over, while it is in progress, from the lives of the audience. This sense of entrance into mental being, rather than into a world of action and suffering, distinguishes these plays. ${ }^{3}$

The psychological penetration and mental concentration constitutive of these dramas make them especially suitable for the representation of that claustrophobic atmosphere which

\footnotetext{
${ }^{2}$ Visual materials about these productions are available on the project site of the Research Group for Cultural Iconology and Semiography (REGCIS): http://www.szeged-english.hu/en/research/regcis My project was supported by the János Bolyai Research Scholarship of the Hungarian Academy of Sciences.

${ }^{3}$ John Bayley, Shakespeare and Tragedy (London and Boston: Routledge, 1981), 164.
} 
characterized life under the repressive socialist regime. The historical-political reading of Shakespeare introduced by Jan Kott of course had its decisive influence in Hungary as well, and nothing was more natural than the politically allegorizing staging of Denmark as a prison or Scotland as a hotbed of tyranny, metaphorically standing for the contemporary political situation in Hungary. ${ }^{4}$ Kott's "Grand Mechanism" was often the central dramaturgical theme in these productions, but two directors made an attempt to combine this political framework with a more expressive vision of the tragedy of consciousness. The filmed stage production of Hamlet by Gábor Bódy and the film of Macbeth by Béla Tarr are representative examples of this perspective, also serving as the starting point of my survey of Macbeth productions in Hungary after the change of the political system.

Gábor Bódy was one of the most important figures in the group of young directors aiming to renew the philosophy of the moving image, combining visual sensitivity with structuralist and semiotic theory to develop his concept of seriality in cinematography, introducing video technology and video editing as a new form of expression. Although not active as a stage director, in 1981 he directed Hamlet in Kisfaludy Theatre Győr and subsequently on film. In this, the stage was the interior of Hamlet's head, and the performance took place in the labyrinthine tunnels, vessels and cavities of this materialized consciousness. Bódy thus presented Shakespeare's play as a tragedy of consciousness, a self-enclosed laboratory of Hamlet's mental activity. The protagonist metaphorically maps out his own consciousness throughout the action by penetrating and walking through and through the interior realms of his brain, full of fibres, nerves, veins and cells that are packed with chains of blinking light bulbs and devices of visual effects. Bódy stages Hamlet's cinematic selfdissection in a postmodern anatomy-theatre in which, Hamlet enters deeper and deeper into this brain that is metaphorical of the feelings, traumas and repressions of his unconscious. The image of being captive of one's own mind resonated with the all-enveloping suffocation of one-party hegemony and cultural censorship, intensified by stage design could also be perceived as an immense ear that will hear everything and implying that, since we are all within its structure, there is no escape from its eavesdropping. ${ }^{5}$

In the same year Béla Tarr produced a film version of Macbeth that displayed remarkable analogies with Bódy's interpretation of Hamlet. Tarr later became one of the most

\footnotetext{
${ }^{4}$ Jan Kott, Shakespeare Our Contemporary, trans. Boleslaw Taborski (Garden City, NY: Doubleday, 1964).

${ }^{5}$ For a more detailed analysis of the film, see my article "Cinematographical Anatomy: Gábor Bódy's Stage of Consciousness,” Apertúra 4, no. 1 (2008), http://apertura.hu/2008/osz/kiss.
} 
acclaimed and celebrated Hungarian art film directors, collecting the most prestigious European awards for his films Sátántangó, The Man from London, and, most recently, The Turin Horse. His medium was the cinema, where he proved as much an innovator as Bódy with the video technique, but he introduced himself with a dramatic adaptation. He directed Macbeth, his very first piece, as the diploma work for his college graduation in 1981. As early as this first attempt, Tarr introduces the cinematographic technique of the long shot, which later became his trade mark. His version of Macbeth, later marketed as a television film, is 62 minutes of continuous camera movement, with one single shot after the main title in the fifth minute. The play is directed in the underground caverns of the Castle of Buda, a system of military fortification. The scene produces the same claustrophobic feeling as the brain-stage devised by Bódy, and in this space of overwhelming captivity the continuous camera movement is an excellent technique to create the feeling of one single consciousness experiencing, producing or projecting all the happenings. Each new character first appears from a side-tunnel of the catacombs and floats into the perspective of the camera, or the camera itself follows the movements of the characters inside this self-enclosed underground world without any natural light.

Tarr builds his reading of the tragedy on his own peculiar cinematic poetics of the face, and Macbeth in his adaptation becomes a long sequence of close-ups where a gradually accelerated rhythm of representations of the face carries us towards the climactic point when Macbeth looks out from the diegetic texture of the film, into the camera, as if making eyecontact with the spectator. This is the scene in which the Weird Sisters initiate him into the visions that show the future reign of Banquo's sons. Until this point, we do not encounter Macbeth's look directly, although the visual emphasis is continuously on the faces, and we see little more than the camera repeatedly zooming on the head and the eyes of the various characters. In other words, no suture is needed in this self-enclosed space for the viewer to identify with the cosmos and the perspectives of the events, as the shot - counter shot technique cannot be employed because of the continuous camera technique and the fixed perspective. We remain outside the universe of the events as observers peeping through the perspective of the camera, but exactly because of this it comes as a shock when Macbeth, contemplating the future, suddenly stares at us, as if the horrible vision he catches sight of was our reality, the world of the audience. It is especially ingenious of Tarr to stage the Weird Sisters so that they embrace Macbeth from behind, firmly holding his head to face the prophetic vision so that it appears as if captured by a frame imposed on it by the supernatural agents. His face is thus transformed into a screen in which we see ourselves. 
If Bódy became famous for his construction of the stage of Hamlet as a dissected brain, Tarr's film had a remarkable effect on the contemporary audience and critics though his extraordinary setting and his characteristically Lévinasian portrayal of the human face. ${ }^{6}$ Another special feature of the film is Tarr's remarkable treatment of the Weird Sisters. Their psychic force is emphasized by the choice of three well-known Hungarian male directors for the roles of the witches. Members of the audience immediately recognized these faces and inserted them in the play's thematic framework in which these demons plant a seed of information in the protagonist's mind that will feed on the passions already in his unconscious, driving the tragic hero into a chain of events supervised by the witches as directors. Space is reduced everywhere in the tunnels of the scene as if, just like in Hamlet's case, we were locked in Macbeth's consciousness. Vertical and horizontal perspectives are continuously barred and restricted. The beginning of the film shows how Macbeth and Banquo enter this underground world, as if in a psychic journey, while the numberless mounted soldiers march behind them, producing a long, uncanny, echoing effect with the noise of the hoof beats: after a while the viewer cannot but think of the hooves of the devil. We are indeed entering hell-castle where the only real vertical camera perspective commences in the single long shot of the film when Macbeth descends even further into this hell and murders Duncan in one of the lower chambers of the fortress. Lady Macbeth watches from the top of a staircase as Macbeth covers the king's corpse at the bottom level of the tragedy's cosmos.

Both Bódy and Tarr laid special emphasis on the representation of the mental processes of the protagonists through a meticulous screening of the mind and the face. Of course, both interpretations were received by the contemporary audience and the community of anti-establishment critics as allegories of the deadlock of the human mind under the binding forces of tyranny. It is equally important to observe that both of these new generation directors were ahead of their times by theorizing and problematizing issues already present in international Shakespeare scholarship and European critical thinking, but which were still far from being canonized and even further away from being imported into Hungary. John Bayley wrote his account of the tragedies of consciousness in 1981, Lévinas was already well established in France and already translated into English but hardly known in Hungary, so the poetics of consciousness and the poetics of the face, as we might define these two adaptations,

\footnotetext{
${ }^{6}$ I am not arguing that Tarr was reading Lévinas, but rather that, like Bódy, he presented critical and interpretive insights before the new European philosophical trends came to Hungary. For the relevant material, see Emmanuel Lévinas, The Lévinas Reader, ed. Seán Hand (Oxford: Basil Blackwell, 1989), 82-83.
} 
were original and innovative interpretive approaches that anticipated and paved the way for interpretive schools that only later gained ground in Hungary.

Besides facilitating the dissemination of international trends in philosophy and literary interpretation, Bódy and Tarr introduced an interpretive stance which was actually taking shape at the time in contemporary theatre theory as a result of what is generally referred to as the semiotic turn. By the late 1970s, a critical debate of several decades was reaching a point when the performance-oriented semiotic approach to dramatic texts gained wider recognition. This approach was a forerunner of later performance studies, and argued that the dramatic text cannot be understood without its being performed on an actual or hypothetical stage. This results from the generic nature of the dramatic text, which is organized in a way that the undecidabilities and blank holes, gaps and information shortages prevent any coherent understanding unless an actual performance space decides how and in what circumstances the events should unfold. The dramatic text is a skeleton which is filled with flesh and actualized as a live event through the performance text that can only emerge on the basis of a particular representational logic. ${ }^{7}$

Dramatic texts are usually designed for the representational logic of the theatre model of the historically specific society, and this representational logic is grounded in the general semiotic disposition of the world model of the given culture. ${ }^{8}$ Glynne Wickham proposed a major transition from the emblematic theatre of the early modern period to the photographic realism of bourgeois theatre, due to the changing conceptions of semiosis and the epistemological stakes of representation. This change is indicative of how the period of modernity replaces the early modern panmetaphoric way of thinking, which had been in place as a way to get to know reality, with a different semiotic disposition. The horizontal and syntagmatic world model of the Enlightenment will no longer be interested in polysemy and will favour a theatrical model where a mimetic representation of the environs reflects the general belief in empirical knowledge. In Shakespeare's time these two theatrical

\footnotetext{
${ }^{7}$ One of the initiators of this semiotic approach was Allan Dessen. See, in particular, Recovering Shakespeare's Theatrical Vocabulary (Cambridge: Cambridge University Press, 1995), 39; Elizabethan Drama and the Viewer's Eye (Chapel Hill: University of North Carolina Press, 1977); and Elizabethan Stage Conventions and Modern Interpreters (Cambridge: Cambridge University Press, 1984).

${ }^{8}$ For the idea of the semiotic disposition of culture and semiotic world models, I rely on Jurij M. Lotman, "Problems in the Typology of Cultures." In Daniel P. Lucid (ed.) Soviet Semiotics (Baltimore: The Johns Hopkins University Press, 1977), 214-220.
} 
representational models were competing, just as the earlier medieval world model of high semioticity was being questioned and dislocated by the emerging modern world model. ${ }^{9}$

These performance-oriented semiotic approaches started to restore the early modern dramatic texts to a hypothetically reconstructed theatrical context and revealed that a large number of dramaturgical uncertainties can only be decided on the basis of a restored representational logic, and that layers of meaning in these dramas are uncovered on the basis of their functioning within a specific theatrical space. These new critical orientations also suggested how the early modern epistemological crisis manifested several analogies with the representational and epistemological crisis of the postmodern period, and a considerable affinity grew in stage producers, directors and performance oriented interpreters for the representational logic of the early modern theatre. I would like to concentrate on a number of elements in the play that have been intensively thematized and experimented with as a result of the attempt to take into consideration the characteristics of the emblematic stage, for which the drama was originally intended. My contention is that the tripartite verticality of the Shakespearean theatre is a recurrent element in recent productions. This axis organizes the space of the early modern emblematic theatre through the levels of the heavens, the earth and the underworld below the trapdoor, and distributes various symbolical elements to the events or characters that predominantly occupy these levels. This verticality is also a constitutive element of tragic irony on the stage, since the inversion in the order of this axis communicates universal disorder and discord. If agents, such as the Weird Sisters that arrive from the underworld through the trapdoor, or characters who originally belong to the stage-level of the earth, start to occupy a metaposition at the higher level of this universe, they will usurp the place of God who might be conspicuously absent from this cosmos. Closely linked to the idea of the underworld is the representation of abjection and corporality, themes that have been much theorized in poststructuralist accounts of the subject, but which must have also functioned as representational techniques on the English Renaissance stage. Finally, postmodern adaptations of Shakespeare rely on the performance-oriented semiotic interpretations which, since the 1970s, have argued that the early modern theatre, above all, aimed at entertaining heterogeneous masses of people. To achieve this objective, the emblematic stage strove to establish a total theatrical semiosis through the polysemous symbolical networks of connotations and the interactive involvement of the audience, and the

\footnotetext{
${ }^{9}$ See Glynne Wickham, Early English Stages, 1300 to 1600 . Volume Two 1576 to 1660, Part I (New York: Columbia University Press, 1963), 155.
} 
performances also tended to mix various genres, linguistic registers and tones to be as entertaining as possible. This quality of genre-heterogeneity is often apparent in Hungarian performances through their emphasis on comic and grotesque elements and potentials of the drama.

Between 1990 and 2012 there have been 23 stage productions of Macbeth in Hungarian theatres. Shakespeare's tragedy has thus been continuously in the repertoire of Hungarian theatres after the changing of the political system, taken up by a number of prominent directors in almost all of the permanent repertory theatres. ${ }^{10}$ The continuing interest in a tragedy that is easy to stage as a political allegory is understandable in a period of transition and uncertainty, when the formation of the democratic system was burdened by the unprocessed and muted heritage of the communist past, the continuities and links between the old state apparatus and the new administration and, perhaps most importantly, the general neurosis that feared the emergence of new centralizing, populist or censorial tendencies. ${ }^{11}$ Three productions close to the birth of the new republic, and two more recent plays, will demonstrate differences and resemblances between the start and finish of this period. These are the productions by the National Theatre Szeged in 1994, Vígszínház Budapest in 1995, and the National Theatre Győr in 1996, and those of Katona József Theatre Budapest in 2008, and Vörösmarty Mihály Theatre Székesfehérvár in 2011.

Compactness characterizes the three performances closer to the 1989 landmark of political restructuring and the beginning of a new social order. This compactness still draws heavily on the technique of mental focus in the tragedy of consciousness to express the concentration of psychic energy, vision and power. The Szeged and Györ productions, respectively of 1994 and 1996, were designed for a smaller studio theatre, while the 1995 Vígszínház Budapest version employs the grand stage of one of the capital's most popular and prestigious theatres. However, even on this stage a self-enclosed elevated green platform stage indicates the separate world of the tragedy. The fact that a "green world" defines and contains the action at the beginning already indicates that the genre boundaries will not be

\footnotetext{
${ }^{10}$ The list of directors includes Róbert Alföldi, László Bagossy, Géza Balkay, András Fésős, Judit Galgóczy, Péter Kálloy Molnár, Csaba Kiss, Tibor Kormos, László Marton, Ferenc Sík, Péter Soós, György Tiwald, Gábor Zsámbéki.

${ }^{11}$ The numbers actually indicate that the popularity of Macbeth increased after 1989. After WW2, between 1945 and 2012, there were 43 productions of the play in Hungary, 20 between 1945 and 1989, and 23 between 1990 and 2012. The first production was in 1950, followed by a 10-year pause. Apparently, Macbeth proved to be more suitable for the continued practice of double coding than its earlier rivals, Hamlet and Richard III. I owe special thanks to Zoltán Imre for this insight and for his generous help in the finalization of this paper.
} 
fully observed, mixing the world of the comedies gets mixed with the gloomy cosmos of the tragedies.

The production in the Szeged studio theatre employs a modernized form of the traditional iconography of the Wheel of Fortune, which, at the same time, also expresses the over-arching dramaturgy of the Grand Mechanism in line with the ideas of Jan Kott. From the circular centre stage a metal runway leads up above the level of the audience at stage left, emblematic of the rise of fortune's wheel on which Macbeth embarks. Repeatedly, Macbeth produces huge clattering noise when ascending this runway and then descends shortly, never being able to secure permanently this metaposition. We only get two levels of the tripartite verticality of the emblematic theatre here, but the continuous traffic on this deafeningly noisy ramp is an apt and ironic way to represent the fragility of power and the ambiguity of the fate prophesied by the supernatural agents. The director, Tibor Kormos laid special emphasis on the relationship between the witches and the Queen, since here Lady Macbeth is one of the three Weird Sisters and her lines are alternately said by the three women. The central theme of the performance is the will to power and the manipulation by the demons: three women in veils and silken robes appear whirling in an other-worldly dance that Macbeth is sucked into, tossed from one woman to another as if in a trance. The hallucinatory atmosphere characterizes the entire play, and it is further intensified when the murder of the king is staged in a prolonged and gruesome scene of torture. Duncan, appearing as a huge naked child, a "naked babe", is butchered ecstatically in centre stage by Macbeth, who then appears to wrestle with the corpse. The regicide drags, pulls and tosses Duncan's cadaver off stage but seems unable to dispose of the weight of the deed.

László Marton also concentrates on the nature of the Weird Sisters in his interpretation 1995 in Vígszínház Budapest, where the witches appear at the beginning of the performance flying in the air, suspended by trapezes and ropes. It is not only the non-earthly nature of these creatures that is immediately foregrounded in this opening scene, but the impression that they come from above, the dimension where some providential plan should be watching over us. Such intervention is, of course, denied, the position of God is usurped by the demons, and they are emblematically joined by Lady Macbeth later who emerges, lying on her bed, through a trapdoor from below. She appeares as a representative of the underworld, herself a "minister of darkness" like the demons she calls upon in her soliloquy.

As mentioned, a separate "green world" on an elevated platform marks out the space of the Weird Sisters, a visionary world resembling a fairy land that is the radical opposite of the grand chamber in the dark and rusty castle of Macbeth where the rest of the play takes 
place. Here, the background is dominated by stairways and a bridge connecting two towers at centre left and centre right.. This bridge or elevation becomes emblematic of the peak of Macbeth's career towards the end of the play, but also grows increasingly instable. The intervention of the demons in the affairs of the humans is not only expressed in their separate green world but also by the way the military strategy of siege against Macbeth is devised by Malcolm. A green branch is dropped in front of him from above, from the world of the witches, and Malcolm, picking it up as a kind of hint, announces that the soldiers should all carry a tree in front of them. The green bough, the green world and the Weird Sisters who are playing comic and grotesque tricks upon Macbeth become interconnected, representing a visionary level where humans are manipulated like puppets by the supernatural forces. The mixture of tragic and comic genres recurs throughout the production. The porter scene invokes roaring laughter in the audience, Macbeth is continuously bordering the ridiculous and the infantile in his march towards insanity, and the spectators also burst into laughter when the Weird Sisters, upon Macbeth's visit and attempt to collect confirmation for the future, literally cook Macbeth. They are standing in the middle of their green world but now, at night, amongst lightning, they fetch Macbeth from the bottom of their cauldron, as if plucking him out of the underworld, and produce fire under the great pot which is, at the same time, a bathtub for the protagonist. Macbeth is boiling in the cauldron together with the fantastic and horrifyingly abject mixture of ingredients that are thrown into the magic soup prepared by the witches, now partly dressed as waitresses with little white aprons that they use to fan the fire. The glee of the spectators quickly turns into shivers when one of the witches offers Macbeth a taste of the bubbling liquid; and then they laugh again when the Weird Sisters massage Macbeth's hands and feet while communicating the apparently reassuring prophecy about the future.

The green world returns in the end when Macduff fights the mentally unbalanced tyrant. Macbeth enters the smaller green platform upstage, but its back edge rises to become a slanted stage that spits out the regicide. Macbeth loses balance, and rolls off the green world to arrive in front of Macduff's feet - one last trick played by the witches.

The most claustrophobic and perhaps most experimental performance of the drama was staged in the tiny studio chamber, the so-called "attic theatre" of Kisfaludy Theatre Györ in 1996. In a condensed space of barely 5 x 5 meters, director Csaba Kiss produced a distilled version of this already concentrated play by limiting the number of characters to four. Other than Macbeth and Lady Macbeth, we only have Banquo and Macduff on the stage in an adaptation that rewrites the roles and considerable parts of the text itself. The speeches of the 
various characters in Shakespeare's original dramatis personae are distributed among these four characters, and the plot is reshaped through a dramaturgy that concentrates on the swelling of the chaos in the protagonist's consciousness.

The initial inversion of cosmic order is shown when Macduff and Banquo do not recognize one another in the confusion of the battle and enter into lethal combat, which is followed by their description of the topsy-turvy world with the words that originally belong to the bloody captain. When Macbeth enters, he plays a trick on his two fellow soldiers by not recognizing them, and describes them as if they were supernatural beings. At this point, it becomes clear that this staging condenses everything into the world of human beings: there are no witches, no transcendental prophesying, and the initial conflict is triggered by the intensified psychological condition of the three soldiers after the shock of the battles. Banquo and Macduff, using the words originally belonging to the Weird Sisters, are teasing Macbeth's mind with promises of his promotion that are presented as jokes, but they find fertile soil in his consciousness to grow into gnawing uncertainty and propelling ambition. The director establishes a psychological architecture for this performance in which no supernatural agency is needed for the events to unfold, since the origin and seat of these conflicts are the human mind. Csaba Kiss provides an intriguing interpretation of the tragedy of consciousness. In his essay he points out that Shakespeare masterfully employs the study of spiritual and mental conflict at dramaturgical points when the spectator would expect an ostentation of horror and a focus on the event itself. Kiss first problematizes the fact that, instead of showing the details of the murder scene, Shakespeare anatomizes the mental terror in Macbeth's mind which metaphorizes the consequences of regicide as the idea of murdering sleep itself. ${ }^{12}$ Throughout the production, the four characters move in a space of immense tension as if they were indeed locked up in Macbeth's consciousness. Kiss also contends that Macbeth's monologues also indicate a difference from other dramas of consciousness where the protagonist also treads a mental path, but he usually moves from a dilemma through meditation to some resolution or decision. Contrary to this, a sudden unconscious content springs up in Macbeth's mind after the initial prophecies, and his consciousness is immediately obsessed with the thought of kingship. This opening up of the unconscious thus establishes a vertical dimension for the play, since we are moving up and down in Macbeth's mental universe, but the staging does not expand this dimensionality in the space of the theatre. Instead of the tripartite spatial organization of the Elizabethan playhouse, here the vertical dimension is limited to being

\footnotetext{
${ }^{12}$ Csaba Kiss, 'Mi van velem, hogy minden zaj ijeszt?' A Macbeth házaspár belső útjai (Budapest, 2006), 2 , http://www.filmacademy.hu/uploads/dokumentumtar/kisscsdolgozat.pdf
} 
locked up in Macbeth's consciousness, but through this interpretation the tragedy of consciousness gains even greater concentration and force.

Although Csaba Kiss does not recourse to the original verticality of the emblematic stage, he does not ignore the emblematic polysemy of stage objects, and employs a limited number of properties that haunt us throughout the entire action. A sword is positioned in centre stage during the play, occupying the focal point of the space, in such a way that it definitely appears to be a cross when it is not being used as a weapon. (Figure 1) The amalgamation of the military and religious-spiritual cultural semantics of the sword foregrounds the ambiguities and indeterminacies in the drama, and in this way the central object becomes the central metaphor which expresses the nature of the cosmos of the play and the human psyche as well. The limited number of stage properties also urges the director to employ a technique characteristic of the emblematic theatre: using the human body to signify. In an ingeniously directed scene, Lady Macbeth whispers the cauldron-song and the words of reassurance, which originally belong to the second prophecy of the witches, as a lullaby into the ears of an exhausted and mentally self-tormented Macbeth. When she utters the equivocations of the witches' words and promises that Macbeth will be invincible, she puts her hands on his head and forms the shape of a crown. (Figure 2)The powerful scene immediately becomes an emblem of their spiritual union which, at the same time, also encapsulates their fate: Lady Macbeth helped her husband to realize the imperial theme, she crowned him, and they will have to fall together.

I now turn to the two more recent productions. Katona József Theatre Budapest, one of the most prominent repertory theatres in the Hungarian capital, staged Macbeth in 2008 in a large-scale and spectacular production which employed almost all the aspects that are in the focus of my performance-oriented semiotic approach. The director Gábor Zsámbéki uses the entire stage to establish the vertical dimensionality of the play: the shining faces of the Weird Sisters appear to be hanging in mid-air in the darkness of the initial scene, and later they repeatedly appear to dwell underground and seem to emerge from various trapdoors. These openings continuously maintain contact and interaction with the underworld: they receive or partially devour corpses, hide and dispatch the witches, and foreground the mysterious, unfathomable abyss under our worldly stage. The verticality that they suggest is further intensified by a prop that is on stage most of the time: a great piece of crystal that is hanging from a metal wire as a pendulum. It descends gradually throughout the events, suggesting that the span of life and action has been measured out for these human beings in advance. 
The Weird Sisters manifest a discomforting mixture of eroticism, mischievous playfulness and abjection. Unmistakably feminine in their transparent white lingerie at the beginning of the play, they obviously address Macbeth's sexual passion when they approach him. (Figure 3) Banquo tears his comrade from the embraces of the not-so-supernaturallooking lustful apparitions, but by then the seed of information is already planted in the protagonist's consciousness, and starts gnawing its way into swelling ambition and mental disintegration. In the central cauldron scene of prophecy the demons produce a horrifying mixture in a large bowl, and their abjection is not just stylized. The stage tableau has a significant force to exercise power on the spectators through the representation of the abject, but the most powerful images follow when Macbeth himself is smeared with the bloody liquid of the witches' foul cocktail, and he is still holding a handful of spongy material, soaking with the mixture, when the equivocators are already gone.

The production relies heavily on spectacle, action and visual symbolism. The shining red of blood on Macbeth's daggers and hands rhymes with the blood on his face and, in the end, on the dead Lady Macbeth's white robe, establishing a visual frame for the play. Macbeth and the Queen wear golden garments after seizing power, but gold turns into white on the insane Lady Macbeth in the sleepwalking scene, into black on Macbeth by the battle, and then into white when he falls in the concluding struggle with Macduff. Zsámbéki stages the fall of the tyrant in an ingenious emblematic tableau: Macduff grabs Macbeth's inert body to lay it on the stiff body of Lady Macbeth. The deceased queen in her white nightshirt is employed as the block on which Macbeth is decapitated, leaving us with a grotesque grin on his face. (Figure 4) The colour symbolism of the white shirt on both Lady Macbeth and Macbeth unites them terminally in death, but also indicates the end of a pilgrimage of mental disintegration, torment and purification. The director uses a typological rhythm of recurring symbolical tableaux throughout the performance, another example of which is the way Lady Macbeth positions her head on a block of stone in her hand-washing scene as if offering herself for beheading. This scene becomes a typological repetition since it rhymes with the blocks of stone that the Weird Sisters are standing on when they are waiting for Macbeth and Banquo at the beginning. These appear to grow from the depth of the earth, from the underworld, and the image is repeated when Macbeth's head is laid upon the Lady's dead body. This final scene turns her body into the block that originally appeared from the underworld to support the weird Sisters, and thus, the circle gets closed: the final tableau brings us back to the original initiators of the events. A mixture of tragic irony and grotesque criticism also reaches its climax in this scene. Lady Macbeth functions as a support that 
Macbeth can lean on throughout his completion of the imperial route - this is represented very spectacularly in the Ghost scene when Macbeth flies from Banquo's apparition in horror, being so frightened that he attempts to climb up the wall of his chamber to take refuge somewhere outside. Lady Macbeth then tries to pull him off the wall. The king is hanging, his knees pulled to his chest to be as far from the ghost as possible, and the embarrassing scene with the ridiculous regicide is about to provoke audience laughter, when Lady Macbeth takes her terrified husband on her shoulder and cries out in immense pain under the weight, both literal and symbolical. The scene is a complex example of how Shakespearean performance can combine the comic with the tragic, the grotesque with the astonishing.

The production is rich in emblematic networks of image clusters that establish a composition of repetition, but this has its toll: the visual spectacle takes away from the mental concentration of the play, and the tragedy of consciousness aspect is mostly limited to the superb facial work of the players.

The last production in my survey is a recent staging in Vörösmarty Mihály Theatre Székesfehérvár, one of the oldest permanent stone theatres outside Budapest. The director Péter Kálloy Molnár excelled in grasping the complexity of genre indeterminacy in the play, succeeding in incorporating the tragic with the grotesque, tragically ironic, farcical or straightforwardly comic and carnivalesque aspects of the drama. It is the framework of tragic irony that this staging is most noteworthy for, and the director relies on the verticality of the emblematic stage in its composition.

Throughout, the comic is mixed with the tragic in Kálloy Molnár's interpretation, which seems to observe the critical hypothesis that the most important objective of English Renaissance tragedy was to provide entertainment for a heterogeneous audience with heterogeneous acting techniques on an almost bare stage. The recurring dilemma about the playful or wicked, earthly or supernatural identity of the witches is answered at the very beginning of the play, when Lady Macbeth appears in the position of a director, educating the Weird Sisters how to act. She teaches them the skills they will employ when they address Macbeth after the battle. (Figure 5) The sisters do not appear especially talented, but with the instructions of Lady Macbeth they act their role as very amateurish but enthusiastic mountebank performers. This staging introduces Lady Macbeth from the very beginning as the great manipulator, who employs the three women to enter and rule Macbeth's mind. She does not simply assist or fuel the witches, but becomes their superior who plays puppetry with them. That Lady Macbeth's puppets, the three sexually provocative women, are the "ministers of darkness" is represented by the fact that they emerge from the orchestra pit, dancing their 
way as apparitions in fog and mist to centre stage in the scene when they meet Macbeth. Although no specific trapdoor technique is employed, the pit definitely suggests the underworld as the home of these creatures of temptation, and the interaction with the underworld is maintained throughout the play, although not by the witches but by Lady Macbeth. In a scenically remarkable solution, a huge well is positioned in the middle of the stage when she reads her husband's letter. First she tests communication with the underworld by throwing pebbles into the well, but later she continues talking and shouting directly into the depth of the well, leaning into its mouth as if trying to peep through the gates of the castle of Beelzebub while conjuring up the agents and forces of hell. When she drops the letter into the well at the end of her monologue of black magic she has sent her message to the underworld: "I am in charge."

The performance is as much about how tragically Lady Macbeth is mistaken in this belief as it is about the fall of the manipulated Macbeth. She is capable of controlling the deeply frightened and concerned Macbeth only to the point when the murderous scheme is performed and the avalanche of bloodshed starts rolling in over the kingdom. When Macbeth realizes that his only survival skill is to eradicate all opposition and all suspects around himself, and decides to remove Banquo, Lady Macbeth suddenly feels him moving outside her control and tries to oppose him, in vain. They argue at the foot of a flight of stairs which ironically provides a vertical counterpart to the well Lady Macbeth uses to communicate with the forces of the underworld. These stairs dominate the visuality of the play, and are representative of the ambition as well as the growing uncontrollability of Macbeth. When the pair stop arguing and climb the stairs together, Macbeth demonstrates his superiority by simply raping his wife on top of the stairs. They got to the top, but Lady Macbeth lost her game of manipulation, and the role Macbeth undertook starts overpowering him uncontrollably, eating up and disintegrating his consciousness.

Lady Macbeth's failure as director of events is also foregrounded by the sleep-walking scene when the well appears again. She makes repeated attempts to hang on to its brim, to find support and renewed recourse to the underworld, but the well, as if to reveal its cynicism, moves away from her and makes her desperate gestures tragically ridiculous. She is betrayed by the supernatural just as much as Macbeth is betrayed by the equivocations of the Weird Sisters. The staging grants independence to the supernatural forces, although the initial representation of the witches as Lady Macbeth's puppets continuously maintains the possibility of seeing them as the driving energies of the unconscious which we temporarily 
seem to control and bend but, if we let them loose, will inevitably compel us to identify with roles that will overpower us.

This dramaturgy is common in Shakespeare's tragedies of consciousness, and I contend that the strength of the production in Székesfehérvár is in the thematization of this typically Renaissance problematic, which has resonances in postmodern epistemological crisis. Early modern English tragedies typically create situations in which the ability of the human being for self-mastery and the control of his or her fate is tested. The consciousness of the protagonist is manipulated by information implanted in his or her consciousness by a supernatural agency (old Hamlet's Ghost, the Weird Sisters); this information defines a task to be completed (revenge, kingship); and the task necessitates the assumption of a role which overpowers the human being and leads to mental disintegration. All Hungarian productions I have discussed observe this model, but it is this recent performance in Székesfehérvár which, I believe, is the most original and successful in creating a tragically ironic framework in which the independent sovereignty of both Macbeth and Lady Macbeth is questioned. This model was a radically pessimistic answer to the epistemological uncertainties of the early modern age in Shakespeare's time, and I believe it triggers a vibrant response in today's audience because the postmodern subject is faced with similar indeterminacies and questions about the sovereignty of the human being.

The tragic irony reaches its climax when the performance shows us that, no matter how high Lady Macbeth aims by reaching to the bottom of the underworld or her unconscious, and no matter how high Macbeth strives to climb over the corpses of his people, the big wheel of fortune, which manifests itself in the image of the imperial stairway, has already turned. The staircase has fallen flat, the vertical already horizontal: there is nowhere to climb. In a series of dream-like and especially acrobatic movements, Macbeth climbs the entire staircase, the upright image of which has dominated the stage until now, but which is now flat. (Figure 6) Macbeth is just crawling on the floor, creating an appearance of climbing up, but he cannot break out of his horizontal fixation. From here, the only route left will be downward, and the tragic irony of the scene is in the brutality of his blindness to this.

My survey of Hungarian Macbeth adaptations did not aim at providing a comprehensive account of the history of the play on the Hungarian stage. Instead, it has highlighted, through the semiotics of performance, aspects of selected stagings that indicate the affinity of today's theatre with the techniques of the early modern emblematic stage. Through the employment of stage verticality, abjection and genre mixing, these productions 
provided ingenious examples of how the problematic of Shakespeare's tragedy of consciousness can be reproduced for a postmodern audience which faces epistemological and moral dilemmas very similar to those of the early modern period. All the productions focus on mental processes and the face as an expressive metaphor of consciousness and psychic concentration, but together they move towards an emphasis on the tragic irony in the play which scrutinizes the sovereignty and autonomy of the human being. The reception history of Macbeth revealed that its popularity increased after the political changes of 1989 . The performances provided interpretations in which the tradition of double coding continued to reflect on the political intensities of a society in transition, but in which the spectators were also compelled to bear witness to the questions of individual and collective human responsibility. Staged as deeply tragic and ironically pathetic at the same time, Macbeth's face keeps looking at us as the face of the fallible Other in which we might recognize ourselves and for which, with all its faults, we have to bear the responsibility.

\section{Works Cited}

Bayley, John. Shakespeare and Tragedy. London and Boston: Routledge, 1981.

Dessen, Allan. Recovering Shakespeare's Theatrical Vocabulary. Cambridge: Cambridge University Press, 1995.

----- Elizabethan Stage Conventions and Modern Interpreters. Cambridge: Cambridge University Press, 1984.

---- Elizabethan Drama and the Viewer's Eye. Chapel Hill: University of North Carolina Press, 1977.

Hawkes, Terence. "Shakespeare and New Critical Approaches." In The Cambridge Companion to Shakespeare Studies, edited by Stanley Wells. 287-302.Cambridge: Cambridge University Press, 1986.

Kiss, Attila. "Cinematographical Anatomy: Gábor Bódy's Stage of Consciousness." Apertúra 4, no. 1 (2008). http://apertura.hu/2008/osz/kiss.

Kott, Jan. Shakespeare Our Contemporary. Translated by Boleslaw Taborski. Garden City, NY: Doubleday, 1964.

Lotman, Jurij M. "Problems in the Typology of Cultures." In Soviet Semiotics, edited by Daniel P. Lucid. 214-220. Baltimore: The Johns Hopkins University Press, 1977.

Kiss, Csaba. 'Mi van velem, hogy minden zaj ijeszt?' A Macbeth házaspár belsö útjai. Budapest, 2006. http://www.filmacademy.hu/uploads/dokumentumtar/kisscsdolgozat.pdf Lévinas, Emmnauel. The Lévinas Reader, edited by Seán Hand. Oxford: Basil Blackwell, 1989.

Wickham, Glynne. Early English Stages, 1300 to 1600 . Volume Two 1576 to 1660, Part I. New York: Columbia University Press, 1963. 